\title{
Evaluation yield and genetically factors in different cultivars of Gladiolus
}

\author{
Mohammad Hossein Azimi ${ }^{1 *}$
}

\begin{abstract}
In order to suggest the best cultivars of gladiolus to grow in moderate regions of Iran, an experiment was carried out in a complete randomized block design in three replications with five cultivars of Gladiolus grandiflorus ('Oscar', 'Red Advance', 'White Prosperity', 'Rose Supreme' and 'Lemon Drop') at the ornamental plants research center in Mahallat city of Iran. In reproductive and yields traits, 'Red Advance' were the highest. The highest vegetative traits were observed in 'Oscar'. The highest spike length $(84.6 \mathrm{~cm})$, number of florets (18.00), vase life (9.33 days) and plant height $(172.88 \mathrm{~cm})$ were observed in 'Oscar'. The highest corm weight $(51.16 \mathrm{~mm})$, numbers of cormlets (54.66) were observed in 'Red Advance'. The results showed that the rate of propagation was high in 'Red Advance'. The highest heritability in traits were estimated as plant height (98.67\%), leaf width (98.66\%), leaf length $(98.12 \%)$, number of florets $(98.55 \%)$, length of spike $(98.90 \%)$ and diameter of stem $(98.84 \%)$. There was a positive and significant correlation between the yield of corm and cormlets with the number of cormlet $(r=0.99)$ and diameter of cormlet $(r=$ $0.96)$ and diameter of cormlet with the number of cormlet $(\mathrm{r}=0.96)$. 'Red Advance' cultivar may be recommended for cultivation as alternative to some oldest cultivars (like 'Oscar'), which showed potentiality for marketing both in domestic and foreign markets. Keywords: Gladiolus grandiflorus Hort., cultivars, corm, cormlet, heritability
\end{abstract}

\section{Introduction}

Gladiolus (Gladiolus grandiflora Hort.) belongs to family Iridaceae, sub-family Ixioideae, tribe Ixieae and sub-tribe (Ranjan et al., 2010), and it is usually called as the queen of bulbous flowers (Randhawa and Mukhopadhyay, 2000). Gladiolus is popularly known as sword lily or corn lily and originated from South Africa (Poon et al., 2012). Gladiolus genus has more than 150 species all over the world that is mainly native of west, south, and east areas of Africa, but about 12 species have originated from Mediterranean areas (Cohat, 1993). Gladiolus has great economic value as a cut flower and for decoration. In Iran it is one of the main bulbous cut flowers and also in the world which has an important role in exporting as cut flowers (Anonymous, 2015).

Corms and cormlets are used for asexual propagation (Moradi and Azimi, 2017). There are spring and summer flowering types of which the summer type is more important and is used extensively to produce cut flowers (Azimi, 2017). Gladiolus had been cultivated all over the world in late $16^{\text {th }}$ century. The most important producers of gladiolus are the United States of America, Netherlands, France, Portugal, Italy, Belgium, Brazil, Australia and India. It has the $8^{\text {th }}$ rank of cut flowers and first rank of bulbous flowers in the world trade (Pragya et al., 2010). According to Misra and Singh (1989), more than 30,000 varieties of gladiolus are cultivated and new cultivars are added annually. The cultivated cultivars in Netherland (more than 10 hectares) include 'White Prosperty', 'Peter Pears', 'Jessica', and 'Green Star'. New cultivars with superior characteristic are substituted annually. Temperatures between 10 and $25{ }^{\circ} \mathrm{C}$ or mild climate are good for grows of gladiolus (International Flower Bulb Center, 2011). Tomiozzo et al. (2018) studied different gladiolus cultivars in various climatic and introduced early cycle ('Purple Flora', 'Rose Friendship' and 'White Friendship') and intermediate cycle ('Green Star' and 'Jester'), produced cut- flower of gladiolus in the favorable model besides as well as having a shorter growth cycle than late cultivars ("Gold Field'), being recommended for commercial cultivation in Southern Brazil. Anuradha and Gowda (1994) studied

\footnotetext{
${ }^{1}$ Ornamental Plants Research Center (OPRC), Horticultural Sciences Research Institute (HSRI), Agricultural Agricultural Research, Education and Extension Organization (AREEO), Mahallat, Iran. *Corresponding author: m.h.azimi58@gmail.com
} 
the genetic variability in 25 genotypes of gladiolus for 24 characters and recorded high degree of variability for all the characters except number of side shots and number of side spikes. High phenotypic and genotypic coefficients of variation were observed for leaf length, number of capsules and number of seeds capsule ${ }^{-1}$, while these were low for number of side spike, floret diameter, floret length and number of leaves. Heritability was low for floret length, longevity of individual floret, days to spike emergence and spike length whereas, genetic advance was high for number of capsules and number of seed capsule.

Several studies have been conducted on gladiolus: different cultivation sites (Tomiozzo et al., 2018), phenology and planting date (Schwab et al., 2015); estimation of genetic variability (Rashmi and Kumar, 2014); heritability and genetic advance (Patra and Mohanty, 2014); genotypic and phenotypic variability (Bhujbal et al., 2013; Pattanaik et al., 2015); and hybridization (Ohri and Khoshoo, 1983a; 1983b; Hossain et al., 2012; Azimi, 2019). Environmental factor in combination with genetic and physiological factors play an important role in determination of plant potential for propagating material. These characters appear to be under strong genetic control (Sukarin et al., 1987; Roy et al., 2004).

The knowledge of phonological steps in bulbous cut flowers can be used as a function of environmental variables in the modification and improvement of these plants' management. The accelerated or delayed stages of plant development are influenced more by genetic factors and less by environmental factors in greenhouse conditions. Therefore, the knowledge of yield and growth steps of gladiolus cultivars can be very important. Demand chains produce flowers on order and dispense them directly to customers (Oliveira et al., 2014).

The producers and consumers now a day are looking for cultivars that produces high yield of cut flowers and increase in the production rate of corms with good quality. The evaluation of genetic variability heritability and identify important yield-attributing characters to provide useful information for developing high yielding gladiolus genotypes is therefore an important aspect of investigation. 'Oscar' is an old cultivar in Iran and new high-yield cultivars need to be replaced. The present research was conducted to identify the suitable, adaptable cultivars for replacing the older ones ('Oscar') in the moderate regions (where the temperature in the summer is between 25 to 30 ${ }^{\circ} \mathrm{C}$ per day and between 20 and $23{ }^{\circ} \mathrm{C}$ at night) of Iran.

\section{Materials and Methods}

Gladiolus cultivars that were used to assess the quality and quantity include 'Oscar' (1), 'Red Advance' (2), 'White Prosperity' (3), 'Rose Supreme' (4) and 'Lemon Drop' (5). The experiments were conducted with three replications in a complete randomized block design and in each replicate 15 corms were planted. This research was conducted in farm at Ornamental Plants Research Center of Mahallat (longitude: $30^{\circ} 27^{\prime} 50^{\prime \prime}$ E., latitude: $30^{\circ} 54^{\prime} 33^{\prime \prime}$ N., altitude: $1747 \mathrm{~m})$.
Growth period (one cycle) was $90 \pm 10$ days from June to late August in 2018. Planting method was basin and the corms were cultivated with a spacing of $15 \times 10 \mathrm{~cm}$. The circumference of corm was used in $8-10 \mathrm{~cm}$. Corms cultivated in loamy soil texture and planting depth was $5 \mathrm{~cm}$.

The characteristics of vegetative evaluated were: 1plant length (from the crown on the surface of the soil to the tip of the stem), 2- leaf width, 3- leaf length, 4- peduncle length, 5- number of floret, 6- length of floret, 7- length of spike (from the first floret to the tip of the flowering branch), 8- diameter of floret, 9- diameter stem, 10- vase life. The conditions for vase life were $20 \pm 2{ }^{\circ} \mathrm{C}, 50 \pm 5 \%$ relative humidity, 12 hours of lighting and 12 hours of darkness, appropriate ventilation, and in urban water $(\mathrm{pH}$ $=7.2 \pm 0.2$ ). The end of vase life was recorded based on the number of days after harvest to $75 \%$ of flower welter (Moradi- Ashur and Azimi, 2017).

Reproductive and yield traits evaluated were: 1 - corm of weight, 2- diameter of corm, 3- number of cormlets, 4diameter of cormlet, 5- cormlet weight and 6-yield of corm and cormlets.

The broad sense heritability, variances and phenotypic, genetic and environmental variability coefficients were calculated based on the methods of Santos et al. (2011): Mse $=$ Mean square error, Mst $=$ Mean square treatment, $\mathrm{R}=$ Replication, $\delta^{2} \mathrm{ph}=$ Phenotypic variance, $\delta^{2} \mathrm{~g}=$ Genotypic variance, $\delta^{2} \mathrm{e}=$ Environmental Variance, $\mu=$ Grand mean of a character, and $\mathrm{h}_{\mathrm{B}}^{2}=$ Heritability in broad sense.

Genetic Coefficient of Variation $(\mathrm{GCV}):\left(\sqrt{ } \delta_{\mathrm{g}} / \mu\right) \times 100$

Phenotypic Coefficient of Variation (PCV): $\left(\sqrt{\delta_{\mathrm{ph}}} / \mu\right) \times 100$

Environmental Coefficient Variation $(\mathrm{ECV}):\left(\sqrt{ } \delta_{\mathrm{e}}^{\mathrm{ph}} / \mu\right) \times 100$ Genetic Variance $\left(\delta^{2}\right)$ : $\left(\mathrm{MS}_{\mathrm{t}}-\mathrm{MS}_{\mathrm{e}}\right) / \mathrm{r}$

Phenotypic Variance $\left(\delta_{\mathrm{ph}}^{2}\right): \delta^{2}+\delta_{\mathrm{g}}{ }_{\mathrm{e}}$

Environmental Variance $\left(\delta^{2}{ }_{\mathrm{e}}^{\mathrm{g}}\right): \delta^{2}{ }_{\mathrm{ph}}-^{2}{ }_{\mathrm{g}}$

Estimation of heritability: $\mathrm{h}_{\mathrm{B}}^{2}=\delta_{\mathrm{g}}{ }^{2} / \delta_{\mathrm{ph}}^{2}$

Statistical analyses including descriptive statistics, simple correlation coefficients, variance analyses and mean comparisons were used with Duncan's test. The analysis of variance procedure of the statistical program SAS version 9.0 (SAS Institute, Cary, NC, USA) was used.

\section{Results and discussion}

Variance analyses showed that the difference of the mentioned cultivars was significant in $1 \% \mathrm{p}$-value for all the studied characteristics showing the varieties for all traits in gladiolus cultivars. In addition, there was a significant difference in $1 \% \mathrm{p}$-value among most blocks (Table 1). Based on the coefficient of variation (C.V.), traits were divided into three groups: the first group with low variability (C.V. $\geq 10$ or less), most of the traits were in this group; the second group was moderate (C.V. $\geq 11$ 20) and third group as high variability (C.V. $\leq 20$ or more), the range of coefficient of variation among traits were $2.50-35.38 \%$ and that the maximum and minimum were for yield of corm and cormlets (35.38\%) and plant height $(2.50 \%)$, respectively (Table 1$)$. 
Table 1. Analysis of variance and estimates of genetic parameters in the evaluated cultivars of gladiolus

\begin{tabular}{|c|c|c|c|c|c|c|c|c|c|c|c|c|c|c|c|c|c|}
\hline $\begin{array}{l}\overrightarrow{0} \\
\dot{0}\end{array}$ & 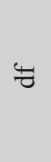 & 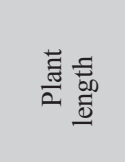 & 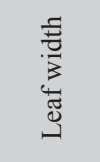 & 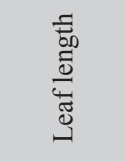 & 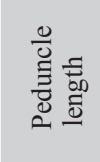 & 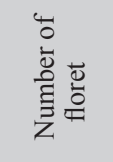 & 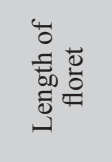 & 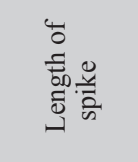 & 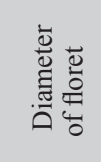 & 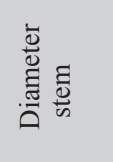 & $\begin{array}{l}\stackrel{\Xi}{\leftrightarrows} \\
0 \\
\stackrel{\mathscr{m}}{7}\end{array}$ & 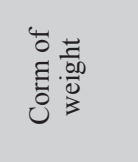 & 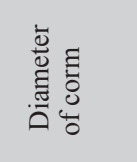 & 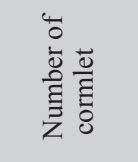 & 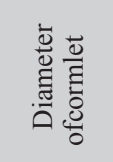 & 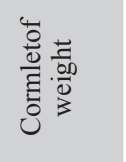 & 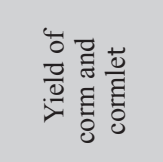 \\
\hline Block & 2 & $23.45^{* *}$ & $0.05^{* *}$ & $18.54 * *$ & $1.62 *$ & $0.89 * *$ & $0.007 \mathrm{~ns}$ & $22.79 * *$ & $0.10^{* *}$ & $0.56^{* *}$ & $0.001^{\mathrm{ns}}$ & $154.69 * *$ & $44.96^{* *}$ & $8.40^{\text {ns }}$ & $0.60^{\mathrm{ns}}$ & $0.06^{\mathrm{ns}}$ & $2187.25^{\mathrm{ns}}$ \\
\hline Cultivar & 4 & $974.64 * *$ & $3.12 * *$ & $192.93 * *$ & $5.97^{\mathrm{ns}}$ & $23.23^{* *}$ & $2.25 * *$ & $828.90 * *$ & $2.02 * *$ & $27.45^{* *}$ & $3.06 * *$ & $599.05 * *$ & $331.14 * *$ & $814.90 * *$ & $23.49 * *$ & $13.79 * *$ & $108107.36^{* *}$ \\
\hline Error & 8 & 13.05 & 0.042 & 3.67 & 2.49 & 0.34 & 0.090 & 9.11 & 0.101 & 0.32 & 0.16 & 50.41 & 30.18 & 28.80 & 3.10 & 0.45 & 5118.61 \\
\hline $\mathrm{CV}(\%)$ & - & 2.50 & 5.13 & 3.57 & 7.99 & 4.09 & 3.25 & 5.45 & 4.09 & 3.83 & 4.86 & 26.39 & 12.25 & 19.82 & 20.64 & 14.07 & 38.35 \\
\hline Genetic variance & - & 970.29 & 3.106 & 191.7 & 5.14 & 23.11 & 2.22 & 825.86 & 1.98 & 27.34 & 3.00 & 582.24 & 321.08 & 805.3 & 22.45 & 13.64 & 106401.2 \\
\hline $\begin{array}{l}\text { Phenotypic } \\
\text { variance }\end{array}$ & - & 983.34 & 3.148 & 195.37 & 7.63 & 23.45 & 2.31 & 834.97 & 2.08 & 27.66 & 3.16 & 632.65 & 351.26 & 834.1 & 25.55 & 14.09 & 111519.8 \\
\hline $\begin{array}{l}\text { Environmental } \\
\text { variance }\end{array}$ & - & 13.05 & 0.042 & 3.67 & 2.49 & 0.34 & 0.09 & 9.11 & 0.10 & 0.32 & 0.16 & 50.41 & 30.18 & 28.8 & 3.10 & 0.44 & 5118.61 \\
\hline $\begin{array}{l}\text { Genetic diversity } \\
(\%)\end{array}$ & - & 21.55 & 12.28 & 70.034 & 24.56 & 61.79 & 36.97 & 53.53 & 9.49 & 62.25 & 3.13 & 89.7 & 39.96 & 10.48 & 98.52 & 43.29 & 17.48 \\
\hline $\begin{array}{l}\text { Phenotypical } \\
\text { diversity (\%) }\end{array}$ & - & 21.69 & 12.36 & 70.708 & 29.92 & 62.25 & 37.71 & 53.82 & 9.73 & 62.61 & 3.21 & 93.5 & 41.79 & 10.67 & 10.51 & 44.00 & 17.90 \\
\hline $\begin{array}{l}\text { Environmental } \\
\text { diversity }(\%)\end{array}$ & - & 2.49 & 1.42 & 9.69 & 17.09 & 7.49 & 7.441 & 5.62 & 2.14 & 6.73 & 0.72 & 26.39 & 12.25 & 19.83 & 36.6 & 7.86 & 38.35 \\
\hline $\begin{array}{l}\text { Broad sense } \\
\text { heritability (\%) }\end{array}$ & - & 98.67 & 98.66 & 98.12 & 67.367 & 98.55 & 96.10 & 98.90 & 95.16 & 98.84 & 94.94 & 92.03 & 91.4 & 96.54 & 87.87 & 96.8 & 95.41 \\
\hline
\end{tabular}

**and *: significant at $1 \%$ and $5 \%$ respectively 
The results showed that among the five cultivars (Table $2)$, the maximum plant height was in "Oscar' $(172.00 \mathrm{~cm})$ and the minimum were for 'White Prosperity' (128.00 $\mathrm{cm})$ which showed the significant difference from the other cultivars (Table 2). The height difference of plants can be for their competitiveness for light, space, moisture, nutrition, and ventilation (Karavadia and Dhaduk, 2002; Dole and Wilkens, 2004). The flower stem height that is one of the important characteristics of cut flowers is market-friendly. Therefore, the results showed that the higher plant has bigger reproductive parts, number of leaves, and area. The higher cultivars increasing qualified production of flowers. In addition, similar findings by Tomiozzo et al. (2018) show that significantly stem height. The stem height of the ornamental flowers is considered as a valuable characteristic of the apparent structure, in spite of, the suitable effect on physiological characteristics increases flowers resistance in transferring from field to market (Azimi et al., 2012). In this research, the used corms sizes were similar. So this observed difference in height of gladiolus cultivars due to the difference in genetic structure and also environmental factors which are similar to that obtained by Hossain et al. (2012). In this context, Moradi (2008) reported that 'Oscar' has the maximum mean height and 'White Prosperty' has the minimum height than the other cultivars and showed the significant difference from the others. Increasing corm size in gladiolus increase height and length of the flower spike, similar results were also reported by Bijimol and Singh (2001)

Among the cultivars, the highest number of florets was found in 'Oscar' (18.11) and the lowest in 'Lemon Drop' (12) (Table 2). Producing spike with more florets happens because of less competitiveness among plants to obtain water, minerals, nutrition, and light (Mojiri and Arzani, 2003). Similar results were reported by Padaganur et al. (2005), Khalaj and Edrisi (2013), and Moradi (2013) on Polianthes tuberosa.

In this regard, Sharma and Goupta (2003) research showed increasing distances cultivation, increases the number of florets in the flower spike. Results of Rai et al. (2000) in various gladiolus cultivars showed in 'White Prosperity' cultivar was 17 and 'Green Wood Pecker' was minimum with 12 florets.

Among the cultivars, the maximum length of the peduncle was in the 'Lemon Drop' (20.22 mm) and 'Red Advance' (20.52 mm), and the lowest in the 'Rose Supreme' (Table 2).

The maximum length and diameter of florets in 'Oscar' 10.49 and $8.91 \mathrm{~cm}$, respectively, and the lowest of these traits in 'White Prosperity' were observed (Table 2). Commercial cultivars with bigger floret have better conditions for sale in flower and plant market. In this way, Moradi (2008) research showed that the 'Rose Supreme' cultivar has the maximum mean floret diameter, and 'White Prosperity' has the minimum mean values for these traits. In this case, Sindhu and Verma (1995) results showed that the biggest floret was obtained with $11.70 \mathrm{~cm}$ in 'Sancera', and the minimum in 'Arc' cultivar with $6 \mathrm{~cm}$. Moreover, in gladiolus cultivars the biggest floret was in 'Rose Supreme' with $8.92 \mathrm{~cm}$, and the biggest one was in 'Slamone Queen' among 12 gladiolus cultivars based on Misra et al. (1987) reports.

Results showed that the maximum length and width (Table 2) of leaf in 'Oscar' were 5.9 and $6.38 \mathrm{~cm}$, respectively, the lowest leaf width was observed in 'White Prosperity' $(2.84 \mathrm{~cm})$ and the minimum leaf length was in 'Rose Supreme' (42.27 cm). In this regard, Moradi (2008) showed that 'Rose Supreme' and 'Orange' cultivars of gladiolus have the maximum and minimum mean leaf width, respectively, and the significant difference was observed than other cultivars. Moreover, 'Oscar' and 'Yellow' cultivars have the maximum and minimum mean leaf length, respectively. Therefore, cultivars with more leaf surface have better quality and quantity indexes. Increasing leaf surface caused photosynthesis and accumulates more carbohydrates which result in vase life. Longer vase life makes it possible to transfer and move them to the further places in flower export (Jozghasemi et al. 2015).

Results showed that the highest stem diameter in gladiolus cultivars (Table 2) was in 'Red Advance' (18.08 $\mathrm{mm}$ ) and the minimum were in 'White Prosperty' (10.66 $\mathrm{mm}$ ) than the other cultivars or they had significant difference statistically from others. In this regard, Moradi (2008) showed that 'Oscar' and 'Yellow' of gladiolus has the maximum and minimum stem diameter mean, respectively among the other cultivars. Moradi and Azimi (2017) showed no significant difference in this characteristic in gladiolus cultivars by evaluating various cultivars performance such as 'Rose Supreme' and 'White Prosperty'. Moreover, the flower stem diameter is one of the valuable characteristics of the cut branch flowers (Tomiozzo et al., 2018) and increases flowers resistance against transference from the garden to sale market (Azimi et al., 2012).

The highest vase life in 'Oscar' (9.33 days) and 'Lemon Drop' cultivar (9.00) days and lowest in 'White Prosperty' (7.00 days) were observed (Table 2). Cultivars with long vase life are significantly important according to the commercial and economic importance of the cut branch flower. The vase life of the cut flower is influenced by before and after cultivation factors. Quality and vase life of the cut flowers depend on cultivation conditions and their transference conditions after cultivation. The florets open in sequence over a longer duration and a bigger spike length with more florets will provide vase life longevity (Dwivedi et al., 2016).

The results showed that among the five cultivars (Table 2), the highest spike length was observed in 'Oscar' (84.16 $\mathrm{cm})$ and the lowest in 'White Prosperty' $(42.47 \mathrm{~cm})$. The sales volume of cut-flower determinant the economic yield. In today's, trade in ornamental plants, demand for flowering plants is higher for cultivars with higher yield and flowering quality (Azimi, 2019). Cut-flowers with stem length, stem diameter and spike length (inflorescence) are standards for marketable (Schwab et al., 2015; Tomiozzo et al., 2018). Choudhary et al. (2011) reported stem length exhibited direct effect on spike length in gladiolus. The results are also in agreement with Lal et al. (1985), Balaram and 
Table 2. Mean squares of traits in cultivars (1 to 5) of gladiolus 'Oscar' (1), 'Red Advance' (2), 'White Prosperity' (3), 'Rose Supreme' (4) and 'Lemon Drop' (5)

\begin{tabular}{|c|c|c|c|c|c|c|c|c|c|c|c|c|c|c|c|c|}
\hline Cultivars & $\begin{array}{l}\text { Plant } \\
\text { length } \\
(\mathrm{cm})\end{array}$ & $\begin{array}{c}\text { Leaf } \\
\text { width } \\
(\mathrm{cm})\end{array}$ & $\begin{array}{c}\text { Leaf } \\
\text { Length } \\
(\mathrm{cm})\end{array}$ & $\begin{array}{c}\text { Peduncle } \\
\text { length } \\
(\mathrm{mm})\end{array}$ & $\begin{array}{l}\text { Number } \\
\text { of floret }\end{array}$ & $\begin{array}{l}\text { Length } \\
\text { of } \\
\text { floret } \\
(\mathrm{cm})\end{array}$ & $\begin{array}{l}\text { Length } \\
\text { of spike } \\
\text { (cm) }\end{array}$ & $\begin{array}{c}\text { Diameter } \\
\text { of floret } \\
\text { (cm) }\end{array}$ & $\begin{array}{c}\text { Diameter } \\
\text { stem } \\
(\mathbf{m m})\end{array}$ & $\begin{array}{c}\text { Vase } \\
\text { life } \\
\text { (day) }\end{array}$ & $\begin{array}{c}\text { Corm of } \\
\text { weight } \\
\text { (g) }\end{array}$ & $\begin{array}{c}\text { Diameter } \\
\text { of corm } \\
(\mathrm{mm})\end{array}$ & $\begin{array}{c}\text { Number } \\
\text { of } \\
\text { cormlet }\end{array}$ & $\begin{array}{c}\text { Diameter } \\
\text { of } \\
\text { cormlet } \\
(\mathbf{m m})\end{array}$ & $\begin{array}{c}\text { Cormlet } \\
\text { of } \\
\text { Weight } \\
\text { (g) }\end{array}$ & $\begin{array}{c}\text { Yield } \\
\text { of corm } \\
\text { and } \\
\text { cormlet }\end{array}$ \\
\hline 1 -'Oscar’ & $172.88 \mathrm{a}$ & $5.09 \mathrm{a}$ & $63.08 \mathrm{a}$ & $20.38 \mathrm{ab}$ & $18.11 \mathrm{a}$ & $10.49 \mathrm{a}$ & $84.16 \mathrm{a}$ & $8.91 \mathrm{a}$ & $17.48 \mathrm{a}$ & $9.33 \mathrm{a}$ & $26.91 \mathrm{~b}$ & $42.57 \mathrm{~b}$ & $30.00 \mathrm{~b}$ & $6.27 \mathrm{c}$ & $5.45 \mathrm{~b}$ & $191.68 \mathrm{~b}$ \\
\hline $\begin{array}{c}2 \text {-'Red } \\
\text { Advance' }\end{array}$ & $143.19 b$ & $4.71 \mathrm{ab}$ & $59.30 \mathrm{~b}$ & $20.52 a$ & $16.50 \mathrm{~b}$ & $9.43 b$ & $52.25 \mathrm{~b}$ & $7.81 \mathrm{~b}$ & $18.08 \mathrm{a}$ & $9.00 \mathrm{a}$ & $51.16 \mathrm{a}$ & $62.86 a$ & $54.66 \mathrm{a}$ & $9.94 \mathrm{ab}$ & $8.30 \mathrm{a}$ & $509.29 \mathrm{a}$ \\
\hline $\begin{array}{l}3 \text {-'White } \\
\text { Prosperity' }\end{array}$ & $128.02 \mathrm{c}$ & $2.84 \mathrm{c}$ & $51.30 \mathrm{c}$ & $19.94 a b$ & $12.11 \mathrm{c}$ & $8.39 \mathrm{c}$ & $42.47 \mathrm{~d}$ & $6.59 \mathrm{c}$ & $10.66 \mathrm{c}$ & $7.00 \mathrm{~b}$ & $15.87 \mathrm{~b}$ & $35.28 \mathrm{~b}$ & $18.00 \mathrm{c}$ & $6.17 \mathrm{c}$ & $3.73 \mathrm{c}$ & $83.10 \mathrm{~b}$ \\
\hline $\begin{array}{l}4 \text {-'Rose } \\
\text { Supreme' }\end{array}$ & $130.16 \mathrm{c}$ & $3.04 \mathrm{c}$ & $42.27 d$ & $17.30 \mathrm{~b}$ & $13.05 \mathrm{c}$ & $8.43 \mathrm{c}$ & $51.47 \mathrm{bc}$ & $7.83 b$ & $13.62 b$ & $7.66 \mathrm{~b}$ & $20.96 b$ & $42.52 b$ & $17.66 \mathrm{c} 15 \mathrm{c}$ & $7.52 b$ & $3.24 \mathrm{c}$ & $78.73 b$ \\
\hline $\begin{array}{l}5 \text { - 'Lemon } \\
\text { Drop' }\end{array}$ & $148.13 b$ & $4.48 b$ & $52.44 \mathrm{c}$ & $20.72 a$ & $12.00 \mathrm{c}$ & $9.41 \mathrm{~b}$ & $46.16 \mathrm{~cd}$ & $7.75 b$ & $14.38 \mathrm{~b}$ & $9.00 \mathrm{a}$ & $19.61 \mathrm{~b}$ & $40.98 b$ & $15.00 \mathrm{c}$ & $12.73 a$ & $3.34 \mathrm{c}$ & $69.81 \mathrm{~b}$ \\
\hline
\end{tabular}

Numbers followed by the same letter are not significantly different in $5 \%$. 
Janakiram (2009), Patra and Mohanty (2015) in gladiolus. Gladiolus cultivars are different to the developmental cycle length, date and location of cultivation can also influence the quantitative parameters of the floral stems (Tomiozzo et al., 2018)

Results showed that the maximum in corm weight $(16.15 \mathrm{~g})$ and corm diameter $(62.86 \mathrm{~mm})$ were found for 'Red Advance' and their minimum in 'White Prosperty' cultivar were $15.87 \mathrm{~g}$ and $35.28 \mathrm{~mm}$, respectively (Table 2). The maximum number of cormlet (54.66) and cormlet weight $(8.30 \mathrm{~g})$ was observed in 'Red Advance' and the minimum in 'Rose supreme'. There was significant statistical difference in cultivars (Table 2). In this regard, Moradi (2008) showed the maximum and minimum cormlet number were for 'Oscar' and 'Yellow' cultivar of gladiolus, respectively. The highest yield (corm and cormlet) in 'Red Advance' was $509.29 \mathrm{~g}$ and the lowest in Lemon Drop' was $69.81 \mathrm{~g}$ (Table 2). The results showed that cultivars with higher yield and production are more appropriate; therefore, it can be used in cultivation and breeding programs.

\section{Correlation among quantitative characteristics}

Correlation coefficients of the quantitative traits among various cultivars (Table 3 ) show that the maximum positive and significant correlation were related to yield of corm and cormlet with number of cormlet $(\mathrm{r}=+0.99)$, cormlet diameter $(\mathrm{r}=+0.96)$, corm weight $(\mathrm{r}=+0.94)$, cormlet diameter with number of cormlet $(\mathrm{r}=+0.96)$, number of cormlet with corm diameter $(\mathrm{r}=+0.94)$ and corm diameter with corm weight $(\mathrm{r}=+0.92)$.

The minimum negative and significant correlation were related to the number of cormlet with vase life $(r=-0.34)$. The results showed that cormlet weight had the minimum correlation with plant height, leaf width and leaf length, peduncle length and number of florets (Table 3 ). In other words, number, weight and diameter of cormlet, and weight and diameter of corm are important in the yield of bulbous plant. This is considered as an important factor in gladiolus and can be evaluated in cultivation and breeding programs. Corm diameter increased by corm weight and influences on physiological traits such as wet and dry weight which are effective on the quantity and quality of the flower yield. Moreover, traits of number and dimeter of cormlet and weight and diameter of corm have a positive and significant phenotype and genetic correlation with yield. This is so important for gladiolus cultivars. This indicates the superiority of the simultaneous selection method for more than one characteristic (Sandhu and et al., 1993; Kearsey and Pooni, 1996). The characteristics of leaf length, leaf number, and heightof plant have the maximum phenotype and genetic coefficients with floret numbers in the plant (Moradi, 2008). It is important to know how to link the various traits to the progress of the program to increase performance. Because one-way selection for traits, regardless of other traits, will not be desirable. Therefore, in corrective programs, one must attention to the correlation between traits (Karami et al., 2005).

Variance component estimation, diversity coefficient and inheritance

Relatively high heritability values, in broad sense (Table 1) were found for plant height (98.67\%), leaf width $(98.66 \%)$, leaf length $(98.12 \%)$, number of floret $(98.55 \%)$, length of spike $(98.90 \%)$ and diameter of stem (98.84\%) while the lower value was found for peduncle length $(67.36 \%)$. In a narrow sense, heritability is of greater importance, it is calculated as a ratio between the additive genotypic variance and total phenotypic variance. The plant height, number of floret and length of spike characters may be applied as useful traits in gladiolus breeding and for selection of hybrids. The estimation of genetic parameters provides information extremely useful for plant breeders (Santos et al., 2011). Cultivars in terms of corm weight had higher genetic and genotypic diversity (Table $1)$. The least of phenotypic and genotypic diversity was observed in the vase life. The greatest for environmental diversity was observed in corm weight. Yield of corm and cormlets showed higher genetic variance than other morphological characters (Table 1). Azimi (2019) observed highest heritability in gladiolus offspring traits were in the number of cormlet and cormlet diameter and the lowest for stem diameter (thickness). This information on genotypic variance, heritability and variation rate allow the identification and quantification of the nature of the action of genes involved in the control of a certain trait, so as to evaluate the efficiency of different improvement strategies (Cruz and Carneiro, 2003).

\section{Conclusions}


Table 3. Correlation of quantitative traits between cultivars of gladiolus

\begin{tabular}{|c|c|c|c|c|c|c|c|c|c|c|c|c|c|c|c|c|}
\hline Traits & 1 & 2 & 3 & 4 & 5 & 6 & 7 & 8 & 9 & 10 & 11 & 12 & 13 & 14 & 15 & 16 \\
\hline 1 - Plant length & 1 & & & & & & & & & & & & & & & \\
\hline 2 - Leaf width & $0.76^{* *}$ & 1 & & & & & & & & & & & & & & \\
\hline 3 - Leaf length & $0.38^{*}$ & 0.23 & 1 & & & & & & & & & & & & & \\
\hline 4 - Peduncle length & $0.90^{* *}$ & $0.71 * *$ & $0.43 *$ & 1 & & & & & & & & & & & & \\
\hline 5 - Number of floret & $0.79 * *$ & $0.71 * *$ & -0.01 & $0.70 * *$ & 1 & & & & & & & & & & & \\
\hline 6 - Length of floret & $0.83 * *$ & $0.69^{* *}$ & $0.40^{*}$ & $0.89 * *$ & $0.68 * *$ & 1 & & & & & & & & & & \\
\hline 7 - Length of spike & $0.73^{* *}$ & $0.73^{* *}$ & $0.47^{*}$ & $0.75^{* *}$ & $0.51^{*}$ & $0.77 * *$ & 1 & & & & & & & & & \\
\hline 8 - Diameter of floret & $0.66^{* *}$ & $0.79 * *$ & 0.20 & $0.77 * *$ & $0.72 * *$ & $0.86^{* *}$ & $0.65 * *$ & 1 & & & & & & & & \\
\hline 9 - Diameter of stem & $0.80 * *$ & $0.62 *$ & $0.50^{*}$ & $0.82 * *$ & $0.73 * *$ & $0.87 * *$ & $0.64 * *$ & $0.80 * *$ & 1 & & & & & & & \\
\hline 10 -Vase life & $0.86^{* *}$ & $0.84 * *$ & 0.14 & $0.76^{* *}$ & $0.79 * *$ & $0.60 *$ & $0.58^{*}$ & $0.60^{*}$ & $0.58^{*}$ & 1 & & & & & & \\
\hline 11 - Corm of weight & 0.23 & $0.62 *$ & 0.13 & 0.26 & 0.23 & $0.49^{*}$ & $0.45^{*}$ & $0.63^{*}$ & $0.45^{*}$ & 0.18 & 1 & & & & & \\
\hline 12 - Diameter of corm & 0.15 & $0.53^{*}$ & 0.06 & 0.19 & 0.20 & $0.44 *$ & $0.33^{*}$ & $0.64^{* *}$ & 0.42 & 0.10 & $0.92 * *$ & 1 & & & & \\
\hline 13 - Number of cormelet & 0.23 & $0.68^{* *}$ & 0.18 & $0.34^{*}$ & 0.23 & $0.52 *$ & $0.58 *$ & $0.71^{* *}$ & $0.44 *$ & 0.24 & $0.94 * *$ & $0.84 * *$ & 1 & & & \\
\hline 14 - Diameter of cormlet & 0.3 & $0.70^{* *}$ & 0.33 & $0.43^{*}$ & 0.23 & $0.55^{*}$ & $0.65 * *$ & $0.73^{* *}$ & $0.50^{*}$ & 0.28 & $0.85 * *$ & $0.77 * *$ & $0.96 * *$ & 1 & & \\
\hline 15 - Cormlet of weight & 0.009 & -0.23 & -0.01 & 0.021 & 0.096 & 0.31 & 0.068 & $0.19 \mathrm{~ns}$ & $0.35^{*}$ & $-0.34 *$ & 0.20 & $0.34 *$ & 0.074 & 0.038 & 1 & \\
\hline $\begin{array}{c}16 \text {-Yield of corm and } \\
\text { cormlet }\end{array}$ & 0.19 & $0.62 * *$ & 0.19 & 0.30 & 0.17 & $0.50^{*}$ & $0.54^{*}$ & $0.67^{* *}$ & $0.43 *$ & 0.17 & $0.94 * *$ & $0.86^{* *}$ & $0.99 * *$ & $0.96 * *$ & 0.14 & 1 \\
\hline
\end{tabular}

** and *: significant at $1 \%$ and $5 \%$ respectively 
According the result, 'Red Advance' have been superior in most traits reproductive and yield (corm and cormlet weight, corm and cormlet diameter and number of cormlets), and can be introduced to the farmers and producers for more gained profit and economic efficiency. The 'Oscar' cultivar is superior in vegetative traits among the cultivars. Regarding the high reproduction rate of 'Red Advance', it is recommended for mass production in less time. It should be noted that in most of the Iranian floriculture, 'White Prosperty' with white flowers are used. In order to diversity into the production of gladiolus, it is possible to replace the 'Red Advance' cultivar with red flowers with instead the 'Oscar' cultivar.

\section{Author Contribution}

M.H.A. ${ }^{0000-0003-1533-1876}$ : designing the experiments, obtaining and analyzing data and writing the scientific article.

\section{Acknowledgements}

The financial support of the Ornamental Plants Research Center is gratefully acknowledged. Also, the author gratefully thanks Mr. Shah-Mohammadi for their constructive suggestions.

\section{References}

ANONYMOUS. Stats of ornamental plants in country. Office of flowers and ornamental plants, medicinal and edible mushrooms. Ministry of Jihade-e-Agriculture, 2015, p.15

ANURADHA, S.; GOWDHA, J.V.N. Correlation studies in Gladiolus. In: Floriculture-Technology, Trades and Trends. (Eds.). Prakash, J. and Bhandry, K.R. Oxford and IBH Publishing Co. Pvt. Ltd. Calcutta, 1994, p.285-287.

AZIMI, M.H. Progeny Test of Crosses among Different Cultivars of Gladiolus. Journal of Plant Productions (Scientific Journal of Agriculture), v.41, n.4, p.29-44, 2019. Doi: 10.22055/PPD.2018.21501.1460

AZIMI, M. H.; JOZGHASEMI, S.; BARBA-GONZALEZ, R. Multivariate analysis of morphological characteristics in Iris germanica hybrids. Euphytica, v.214, p.161, 2018. DOI: https://doi.org/10.1007/s10681-018-2239-7

AZIMI, M.H. Introduction to genetic breeding and the creation of new varieties of gladiolus. Ornamental Plants Research Center (OPRC), Horticultural Sciences Research Institute, Agricultural Research, Education and Extension Organization (AREEO), n. 52639, p.22, 2017.
V.; KHAZAEI, F.; FATHI-HAFASHJANI, A. Genetic variation of Iranian Iris species using morphological characteristics and RAPD markers. International Journal of Agricultural Science, v.2, n.9, 875-889, 2012.

BALARAM, M.V.; JANAKIRAM, T. Correlation and path coefficient analysis in gladiolus. Journal of Ornamental Horticulture, v.12, n.1, 22-29, 2009.

BIJIMOL, G.; SINGH, A. Effect of spacing and nitrogen on gladiolus under Nagaland condition. Journal of Ornamental Horticulture New,v.4, n.1, p.36-39, 2001.

CHOUDHARY, M.; MOOND, S.K.; KUMARI, A. Correlation studies in gladiolus. Research in Plant Biology, v.1, n.4, 68-72, 2011.

COHAT, J. Gladiolus. In: The physiology of flower bulbs. Elsevier Science Publication. Amsterdam, 1993, p.297320.

CRUZ, C.D.; CARNEIRO, P.C.S. Modelos biométricos aplicados ao melhoramento genetico. 2.ed. Viçosa: UFV, 2003. p.585. vol2.

DWIVEDI, S.K.; ARORA, A.; SINGH, V.P.; SAIRAM, R.P.; BHATTACHARYA, R.C. Effect of sodium nitroprusside on differential activity of antioxidants and expression of SAGs in relation to vase life of gladiolus cut flowers. Scientia Horticulture, v.210, p.158-165, 2016. Doi: doi.org/10.1016/j.scienta.2016.07.024

HOSSAIN, M.D.; BHUIYAN, M.S.R.; TALUKDER, K.H.; ISLAM, M.R.; SYED, M.A. Study on vegetative propagating materials, flower characteristics and production of true seed through crossing among the different gladiolus genotypes. Advances in Biological Research, v.6, n.2, p.52-58, 2012.

INTERNATIONALFLOWER BULB CENTRE. Gladiolus as cut flowers: Guidelines for cut flower production, 2011. Accessed on Sept 26, 2018.

DOLE, J.M.; WILKENS, H. Floriculture: Principles and Species, 2ed. Pearson. Amsterdam, 2004, p.1048.

JOZGHASEMI, S.; RABIEI, V.; SOLEYMANI, A. Evaluation of the pigments concentration in the Iris species native to Iran. Journal of Biodiversity and Environmental, v.6, n.1, 557-561, 2015.

KARAMI, E.; GHANNADHA, M. R.; NAGHAVI, M. R.; MARDI, M. An evolution of drought resistance in Barley. Iranian Journal Agriculture Science, v.36, n.3, p.547560, 2005. 
and nitrogen on annual chrysanthemum (Chrysanthemum coronarium) cv. Local white. Journal of Ornamental Horticulture New, v.5, n.1, p.65-66, 2002.

KEARSEY, M.J.; POONI, H.S. The genetically analysis of quantitative traits. Chapman and Hall, 1996, p.380.

KHALAJ, M.A; EDRISI, B. The effect of nitrogen and planting density on growth indexes and consumption of highly concentrated elements in the double cultivar of Polianthes tuberosa. Journal of Horticulture, n.27, v.1, p.66-59, 2013.

LAL, S.D.; SHAH, A.; SETH, J.N. Genetic variability in gladiolus. II. Correlations between important yield contributing characters. Progressive Horticulture, v.17, n.1, p.31-34, 1985.

MEMON, N.; QASIM, M.; JASKANI, M.J.; AHMED, R.; AHMED, I. Enhancement of corm and cormle production in gladiolus (Gladiolus spp.). New Zealand Journal of Crop and Horticultural Science, v.37, n.4, p.319-325, 2009.

MISRA, R.L.; SINGH, B. Gladiolus. In: BOSE, T.K.; YADAV, L.P. (ed.) Commercial Flowers. Calcutta: Naya Prokash, 1989. p.253-267.

MOJIRI, A.; ARZANI, A. Effects of nitrogen rate and plant density on yield and yield components of sunflower. Journal Science and Technology Agriculture and Natural Resources, v.7, n.2, p.115-125, 2003.

MORADI-ASHUR, B.; AZIMI, M.H. Increasing qualitative and quantitative indexes of Gladiolus grandiflorus plant density and cultivation method. Scientific Journal of Promotion on Ornamental Flowers and Ornamental Plants, v.2, n.2, p.61-68, 2017.

MORADI-ASHUR, B. Investigating the effect of cultivation method, date, and depth on quantitative and qualitative characteristics of Gladiolus grandifloras cultivars. Ornamental Plants Research Center (OPRC), Horticultural Sciences Research Institute, Agricultural Research, Education and Extension Organization (AREEO), 2013, p.25.

MORADI-ASHUR, B. Evaluation of genetic diversity of quantitative characteristics and selection of single plants for their growth in Gladiolus grandifloras varieties. Ornamental Plants Research Center (OPRC), Horticultural Sciences Research Institute, Agricultural Research, Education and Extension Organization (AREEO), 2008, p.63.

MORADI-ASHUR, B.; AZIMI, M.H. Increasing qualitative and quantitative indexes of Gladiolus grandiflorus bush density and cultivation method. Scientific Journal of Promotion on Ornamental Flowers and Ornamental Plants, v.2, n.2, p.61-68, 2017.

PADAGANUR, V. G.; MOKASHI, A.N.; PATIL, V.S. Effect of growth regulators on growth and yield of Tuberose Cv. Single. Karnataka Journal of Agriculture Science, v.18, n.2, p.469-473, 2005.

PATRA, S.K.; MOHANTY, C.R. Path coefficient analysis in Gladiolus. Journal of Agriculture and Veterinary Science, v.8, n.2, 28-32, 2015.

PATRA, S.K.; MOHANTY, C.R. Variability Studies in Gladiolus. The Asian Journal of Horticulture, v.2, n.9, p.352-355, 2014.

POON, T. B.; POKHREL, A.; SHRESTHA, S.; SHARMA, S.R.; SHARMA, K.R.; DEV, M.B.L. Influence of intervarietal and interspecific crosses on seed set of gladiolus under midhill environments of Dailekh condition. Nepal Journal of Science and Technology, v.13, n.1, p.17-24, 2012.

PRAGYA, J.K.; RANJAN, B.L.; ATTRI, B.; DAS, H.K.; AHMED, N. Performance of gladiolus genotypes for cut flower and corm production under high altitude of Uttarakh. Indian Journal of Horticulture, v.67, p.386-390, 2010.

RANDHAWA, S.; MUKHOPADHYAY, S.P. Promising varieties of gladiolus for commercial floriculture. Haryana Journal of Horticulture Science, v.24, n.3-4, p.197-203, 2000.

RANJAN, P.; BHAT, K.V.; MISRA, R.L.; SINGH, S.K.; RANJAN, J.K. Relationship of Gladiolus cultivars inferred from fluorescence based on AFLP Markers. Science of Horticulture, v.123, n.4, p.562-567, 2010.

TOMIOZZO, R.; PAULA, G.M.; STRECK, N.A.; UHLMANN, L.O.; BECKER, C.C.; SCHWAB, N.T.; MUTTONI, M.; ALBERTO, C.M. Cycle duration and quality of gladiolus floral stems in three locations of Southern Brazil. Ornamental Horticulture, v.24, n.4, p.317-326, 2018. Doi: http://dx.doi.org/10.14295/ oh.v24i4.1237

OLIVEIRA, R.; POZZEBON, M.; VAN HECK, E. Veiling Holambra - Trading Brazilian flowers in the international market enabled by IT. Journal of Information Technology Case and Application Research, v.9, n.1, p.38-58, 2007. Doi: 10.1080/15228053.2007.10856106

SANDHU, G.P.S.; SHARMA, S.C.; ARORA, J.S. Association among morphological traits in gladiolus. Punjab -Horticulture Journal, v.30, n.1-4, p.191-195, 1993.

SANTOS, E.A.; SOUZA, M.M.; ALMEIDA, A.A.F.; 
FREITAS, J.C.O.; LAWINSCKY, P.R. Multivariate analysis of morphological characteristics of two species of passion flower with ornamental potential and of hybrids between them. Genetics and Molecular Research, v.10, n.4, p.2457-2471, 2011. DOI: 10.4238/2011.October.13.3

SCHWAB, N.T.; STRECK, N.A.; BECKER, C.C.; LANGNER, J.A.; UHLMANN, L.O.; RIBEIRO, B.S.M.R. A phenological scale for the development of Gladiolus. Annals of Applied Biology, v.166, p.496-507, 2015. Doi: dx.doi.org/10.1111/aab.12198

SHARMA, J.R.; GOUPTA, R.B. Effect of corm size and spacing on growth, flowering and corm production in gladiolus. Journal of Ornamental Horticulture, v.6, p.352-356, 2003.

SINDHU, S.S.; VERMA, T.S. Promising varieties of gladiolus for commercial floriculture. Haryana Journal of Horticultural Sciences, v.24, n.4, p.197-203, 1995.

SINGH, A. K.; SINGH, O. P.; GUPTA, S. R. Genetic variability and character association in gladiolus (Gladiolus floribundus). Advances in Plant Sciences, n.13, v.1, p.3942, 2000. 